Check for updates

Cite this: Phys. Chem. Chem. Phys. 2017, 19, 22700

Received 8th July 2017, Accepted 2nd August 2017

DOI: $10.1039 / \mathrm{c} 7 \mathrm{cp} 04601 \mathrm{~d}$

rsc.li/pccp

\section{Mediated water electrolysis in biphasic systems $\dagger$}

\author{
Micheál D. Scanlon, (DD *a Pekka Peljo, (D) ${ }^{\mathrm{b}}$ Lucie Rivier, $^{\mathrm{b}}$ Heron Vrubel $^{\mathrm{b}}$ and \\ Hubert H. Girault (D)*b
}

\begin{abstract}
The concept of efficient electrolysis by linking photoelectrochemical biphasic $\mathrm{H}_{2}$ evolution and water oxidation processes in the cathodic and anodic compartments of an $\mathrm{H}$-cell, respectively, is introduced. Overpotentials at the cathode and anode are minimised by incorporating light-driven elements into both biphasic reactions. The concepts viability is demonstrated by electrochemical $\mathrm{H}_{2}$ production from water splitting utilising a polarised water-organic interface in the cathodic compartment of a prototype $\mathrm{H}$-cell. At the cathode the reduction of decamethylferrocenium cations $\left(\left[\mathrm{Cp}_{2}{ }^{*} \mathrm{Fe}^{(I I I)}\right]^{+}\right)$to neutral decamethylferrocene $\left(\mathrm{Cp}_{2}{ }^{*} \mathrm{Fe}^{(\mathrm{III})}\right.$ in 1,2-dichloroethane (DCE) solvent takes place at the solid electrode/oil interface. This electron transfer process induces the ion transfer of a proton across the immiscible water/oil interface to maintain electroneutrality in the oil phase. The oil-solubilised proton immediately reacts with $\mathrm{Cp}_{2}{ }^{*} \mathrm{Fe}^{\text {(II) }}$ to form the corresponding hydride species, $\left[\mathrm{Cp}_{2}{ }^{\star} \mathrm{Fe}^{(\mathrm{IV})}(\mathrm{H})\right]^{+}$. Subsequently, $\left[\mathrm{Cp}_{2}{ }^{*} \mathrm{Fe} \mathrm{IV}^{(\mathrm{IV})}(\mathrm{H})\right]^{+}$spontaneously undergoes a chemical reaction in the oil phase to evolve hydrogen gas $\left(\mathrm{H}_{2}\right)$ and regenerate $\left[\mathrm{Cp}_{2}{ }^{*} \mathrm{Fe}^{(I I I)}\right]^{+}$, whereupon this catalytic Electrochemical, Chemical, Chemical $\left(E C C^{\prime}\right)$ cycle is repeated. During biphasic electrolysis, the stability and recyclability of the $\left[\mathrm{Cp}_{2}{ }^{*} \mathrm{Fe}^{(\mathrm{III})}\right]^{+} / \mathrm{Cp}_{2}{ }^{*} \mathrm{Fe}^{(\mathrm{II})}$ redox couple were confirmed by chronoamperometric measurements and, furthermore, the steady-state concentration of $\left[\mathrm{Cp}_{2}{ }^{*} \mathrm{Fe}^{(I I I)}\right]^{+}$ monitored in situ by UV/vis spectroscopy. Post-biphasic electrolysis, the presence of $\mathrm{H}_{2}$ in the headspace of the cathodic compartment was established by sampling with gas chromatography. The rate of the biphasic hydrogen evolution reaction (HER) was enhanced by redox electrocatalysis in the presence of floating catalytic molybdenum carbide $\left(\mathrm{MO}_{2} \mathrm{C}\right)$ microparticles at the immiscible water/oil interface. The use of a superhydrophobic organic electrolyte salt was critical to ensure proton transfer from water to oil, and not anion transfer from oil to water, in order to maintain electroneutrality after electron transfer. The design, testing and successful optimisation of the operation of the biphasic electrolysis cell under dark conditions with $\mathrm{Cp}_{2}{ }^{*} \mathrm{Fe}^{(\mathrm{II})}$ lays the foundation for the achievement of photo-induced biphasic water electrolysis at low overpotentials using another metallocene, decamethylrutheneocene $\left(\mathrm{Cp}_{2}{ }^{*} \mathrm{Ru}^{(\mathrm{II})}\right)$. Critically, $\mathrm{Cp}_{2}{ }^{*} \mathrm{Ru}^{(\mathrm{II})}$ may be recycled at a potential more positive than that of proton reduction in DCE.
\end{abstract}

\section{Introduction}

Hydrogen $\left(\mathrm{H}_{2}\right)$ production from water splitting using electricity produced from diverse renewable resources (wind, solar, hydro, etc.) is a technological concept that lies at the heart of current efforts to power society with limitless clean energy. ${ }^{1}$ Innovative approaches to water electrolysis are subject to intense research efforts, ${ }^{2}$ particularly to minimise overpotentials (energy losses)

\footnotetext{
${ }^{a}$ The Bernal Institute and Department of Chemical Sciences, School of Natural Sciences, University of Limerick (UL), Limerick V94 T9PX, Ireland. E-mail: micheal.scanlon@ul.ie; Tel: +353-61-237760

${ }^{b}$ Laboratoire d'Electrochimie Physique et Analytique (LEPA), Ecole Polytechnique Fédérale de Lausanne (EPFL) Rue de l'Industrie 17, CH-1951 Sion, Switzerland. E-mail: hubert.girault@epfl.ch; Tel: +41-21-6933151

$\dagger$ Electronic supplementary information (ESI) available: Details of experimental methods, images of the $\mathrm{H}$-cell prototype, cyclic voltammetry and gas chromatography data. See DOI: 10.1039/c7cp04601d
}

for the half-reactions, the cathodic hydrogen evolution reaction (HER) and anodic water oxidation reaction (WOR). ${ }^{3}$

Liquid-liquid interfaces, or interfaces between two immiscible electrolyte solutions (ITIES), possess features suitable to engineer innovative artificial photosynthetic Z-schemes capable of driving energetically uphill chemical reactions. ${ }^{4}$ Waterorganic interfaces can be "dye-sensitised" with molecular photosensitisers, ${ }^{5}$ or trap semiconductor nanomaterials through interfacial surface tension. ${ }^{6}$ A hydrophobicity gradient across the ITIES facilitates spatial separation of charge carriers on either side of the interface. ${ }^{7}$ Aligning the latter with the interface's defect-free nature, electron-hole pair recombination can be reduced. Importantly, water-organic interfaces can be polarised either via application of external voltage by a potentiostat or chemically by dissolving a common ion in both phases. ${ }^{8}$ This key feature provides a mechanism to controllably enhance the efficiency of interfacial charge transfer, ranging from ion 
transfer (IT), to electron transfer (ET) to photo-induced electron transfer (PET).

Rastgar et al. demonstrated that such a Z-scheme can enhance the photochemical behaviour of hyperbranched bismuth vanadate $\left(\mathrm{BiVO}_{4}\right)$ semiconductor nanostructures for visible lightdriven oxidation of water. ${ }^{9}$ BiVO $_{4}$ nanoparticles were assembled at a water-butyronitrile interface, the interface was polarised chemically by distribution of hydrophobic tetraalkylammonium cations, and an oil soluble $\mathrm{Co}^{(\mathrm{III})}$ complex, $\left[\mathrm{Co}(\mathrm{bpy})_{3}\right]\left(\mathrm{PF}_{6}\right)_{3}$, was present in the organic phase to act as an electron acceptor. Detrimental interfacial recombination of electron-hole pairs was minimised through the advanced high-surface area hyperbranching structure of the $\mathrm{BiVO}_{4}$ nanoparticles and defect-free nature of the waterorganic interfacial support. Combining the latter with the additional thermodynamic driving force for interfacial PET from water to the $\mathrm{Co}^{(\mathrm{III})}$ acceptor molecule provided by chemically polarising the water-organic interface, ultimately, led to improved WOR activity compared with $\mathrm{BiVO}_{4}$ photocatalyst powders dispersed in homogenous aqueous solutions. ${ }^{9}$

A key aspect of Rastgar et al.'s research is the electrochemically reversible nature of the $\mathrm{Co}^{(\mathrm{III})} / \mathrm{Co}^{(\mathrm{II})}$ electron acceptor redox couple. This feature allowed the PET process taking place at the $\mathrm{BiVO}_{4}$ functionalised interface to be probed by recycling the $\mathrm{Co}^{(\mathrm{III})} / \mathrm{Co}^{(\mathrm{II})}$ species at the tip of a microelectrode immersed in the organic phase using a scanning electrochemical microscopy (SECM) configuration. ${ }^{9}$ The reversible nature of the $\mathrm{Co}^{(\mathrm{III})} / \mathrm{Co}^{(\mathrm{II})}$ electron acceptor redox couple also facilitates integration of this light-driven biphasic approach to the WOR into the anodic compartment of an electrolysis H-cell (Scheme 1). The advantage is that the overall energy required to achieve the WOR is split between energy provided electrically (to electrochemically oxidise photo-reduced $\left[\mathrm{Co}(\mathrm{bpy})_{3}\right]^{2+}$ ) and energy provided from light (to induce the interfacial PET process). Thus, the electrical energy provided from renewable resources can be utilised much more efficiently than via an approach where $100 \%$ of the driving force for the WOR is provided electrochemically.

Polarised water-organic interfaces can also act as "proton pumps". ${ }^{10}$ Positive polarisation of the interface (by a potentiostat or chemically) may induce either direct transfer of protons from the water to organic phase, or protons may undergo facilitated ion transfer (FIT) if a suitable molecule in the organic phase is capable of interfacial proton complexation. ${ }^{10}$ In a series of articles, Girault and co-workers demonstrated that various metallocenes are capable of the latter, forming hydride species. ${ }^{10-13}$ Depending on the nature of the metallocene-hydride, $\mathrm{H}_{2}$ is evolved homogeneously in the organic phase either spontaneously or by photo-exciting the hydride (see ESI-2, ESI $\dagger$ for a more detailed discussion on this point).

Table 1 summaries the relative formal reduction potentials of a series of metallocenes in a 1,2-dichloroethane (DCE) organic phase. Proton reduction is thermodynamically more favourable in an organic solvent, such as DCE, than in water. ${ }^{14}$ By harnessing the "proton pumping" capabilities of the water-organic interface, $\mathrm{H}_{2}$ is evolved using mild oil soluble electron donor species with high (positive) redox potentials. Thus, in one respect, less electrical energy needs to be applied to an electrode surface to recycle the oxidised species after $\mathrm{H}_{2}$ evolution with such electrochemically reversible electron donors. However, it must

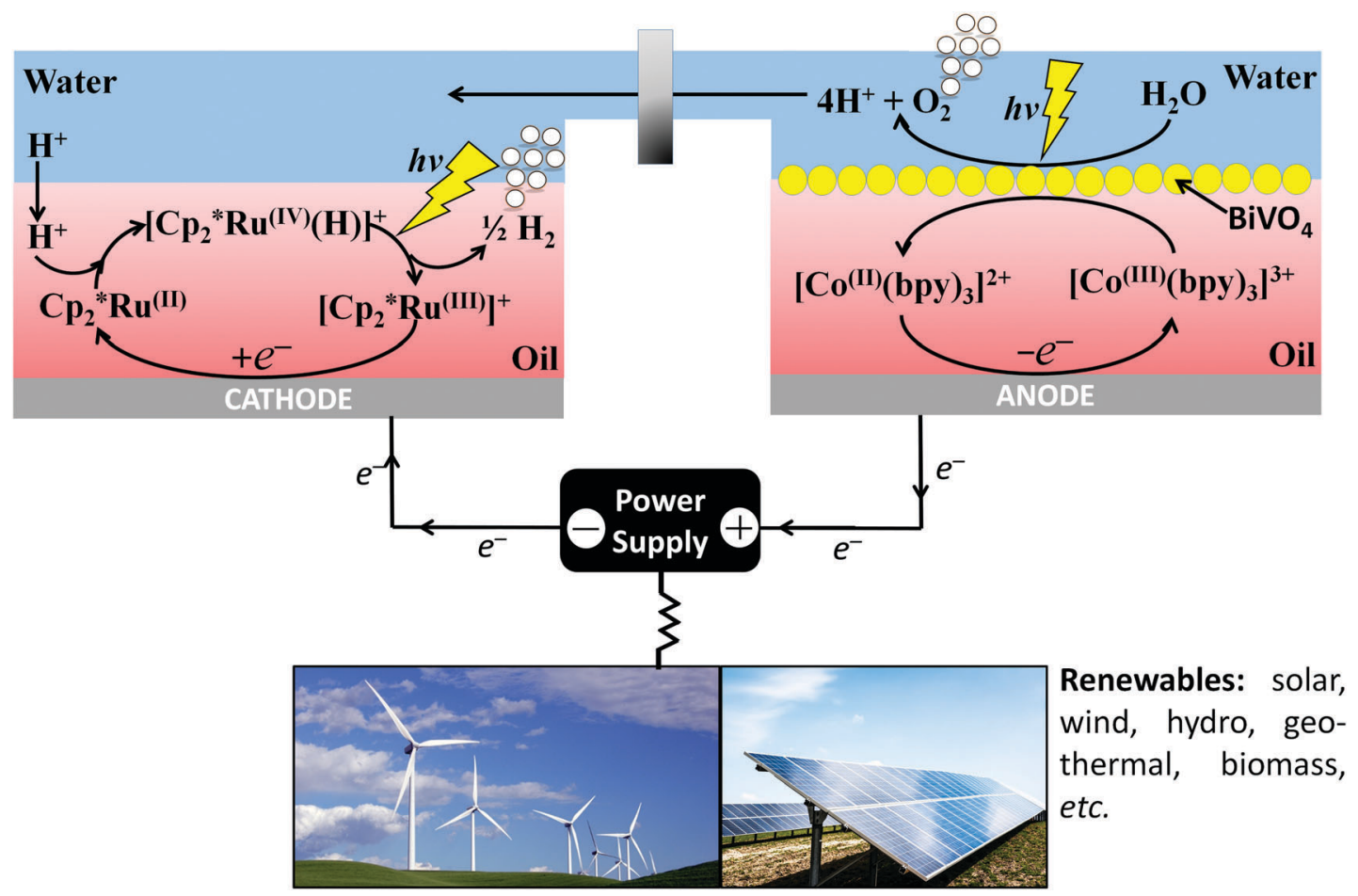

Scheme 1 Concept of water splitting by electrolysis using an $\mathrm{H}$-cell incorporating photo-driven biphasic $\mathrm{H}_{2}$ evolution in the cathodic compartment and photo-driven biphasic water oxidation in the anodic compartment. 
Table 1 Formal reduction potentials of a series of metallocenes in a DCE organic phase, versus the Standard Hydrogen Electrode (SHE) and versus the formal reduction potential of the ferrocenium cation/ferrocene $\left(\left[\mathrm{Cp}_{2} \mathrm{Fe}^{(I I I)}\right]^{+} / \mathrm{Cp}_{2} \mathrm{Fe} \mathrm{III}^{(\mathrm{II})}\right)$ redox couple in DCE

\begin{tabular}{|c|c|c|c|}
\hline Redox couple & {$\left[E_{(\mathrm{ox} / \mathrm{red})}^{0^{\prime}}\right]^{\mathrm{DCE}}(\mathrm{V} v s . \mathrm{SHE})$} & {$\left[E_{(\mathrm{ox} / \mathrm{red})}^{0^{\prime}}\right]^{\mathrm{DCE}}\left(\mathrm{V}\right.$ vs. $\left.\left[\mathrm{Cp}_{2} \mathrm{Fe}^{(\mathrm{III})}\right]^{+} / \mathrm{Cp}_{2} \mathrm{Fe}^{(\mathrm{II})}\right)$} & Ref. \\
\hline$\left[\mathrm{Cp}_{2}{ }^{*} \mathrm{Fe}^{(\mathrm{III})}\right]^{+} / \mathrm{Cp}_{2}{ }^{*} \mathrm{Fe}^{(\mathrm{II})}$ & 0.04 & -0.60 & 15 \\
\hline$\left[\mathrm{Cp}_{2} \mathrm{Fe}^{(\mathrm{III})}\right]^{+} / \mathrm{Cp}_{2} \mathrm{Fe}^{(\mathrm{II})}$ & 0.64 & 0 & 14,16 and 17 \\
\hline$\left[\mathrm{Cp}_{2}{ }^{*} \mathrm{Ru}^{(\mathrm{III})}\right]^{+} / \mathrm{Cp}_{2}{ }^{*} \mathrm{Ru}^{(\mathrm{II})}$ & 0.75 & 0.11 & 18 \\
\hline$\left[\mathrm{Cp}_{2} \mathrm{Os}^{(\mathrm{III})}\right]^{+} / \mathrm{Cp}_{2} \mathrm{Os}^{(\mathrm{II})}$ & 1.03 & 0.39 & 11 \\
\hline
\end{tabular}

be noted these energy gains are negated by the Gibbs energy expended to transfer the protons from the water to oil phase initially.

To overcome the latter, Rivier et al. established that decamethylruthenocene $\left(\mathrm{Cp}_{2}{ }^{*} \mathrm{Ru}^{(\mathrm{II})} ; \mathrm{Cp}^{*}=\mathrm{C}_{5} \mathrm{Me}_{5}\right)$ is capable of reducing organic solubilised protons (through a hydride intermediate) under photo-activation via a catalytic Electrochemical, Chemical, Chemical (ECC') mechanism (Scheme 2). ${ }^{18}$ In the $\mathrm{ECC}^{\prime}$ mechanism the overall energy required to achieve proton reduction is split between energy provided electrically (to electrochemically reduce photo-oxidised $\left.\left[\mathrm{Cp}_{2}{ }^{*} \mathrm{Ru}^{(\mathrm{III})}\right]^{+}\right)$and energy provided from light (to excite the hydride to evolve $\mathrm{H}_{2}$ ). Therefore, as with the biphasic WOR, the driving force for the HER is not solely electrochemical in nature. This is reflected by the regeneration of $\left[\mathrm{Cp}_{2}{ }^{*} \mathrm{Ru}^{(\mathrm{III})}\right]^{+}$at a more positive potential than that of proton reduction in DCE. ${ }^{18}$

A key finding was a set of experimental conditions to stabilise $\left[\mathrm{Cp}_{2}{ }^{*} \mathrm{Ru}^{(\mathrm{III})}\right]^{+}$on a time-scale sufficient to permit its electrochemical regeneration..$^{18}$ Thus, as illustrated in Scheme 1, the latter allows the reversible nature of $\left[\mathrm{Cp}_{2}{ }^{*} \mathrm{Ru}^{(\mathrm{III})}\right]^{+} / \mathrm{Cp}_{2}{ }^{*} \mathrm{Ru}^{(\mathrm{II})}$ to be exploited by integration of this light-driven biphasic approach to the HER into the cathodic compartment of an electrolysis H-cell. Critically, with $\mathrm{Cp}_{2}{ }^{*} \mathrm{Ru}^{(\mathrm{II})}$, the energy saved recycling the oxidised mediator species in DCE after photo-induced $\mathrm{H}_{2}$ evolution (in comparison to directly reducing aqueous protons) is greater than the energy required to pump protons across the interface.

Considering Scheme 1 in its totality, protons released during the photo-driven WOR in the anodic compartment are subsequently pumped across the water-organic interface in the

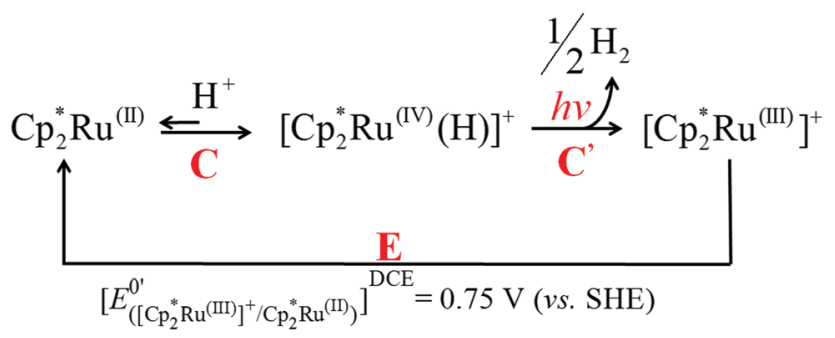

Scheme 2 Mechanism of the catalytic Electrochemical, Chemical, Chemical $\left(E C C^{\prime}\right)$ reduction of protons by $\mathrm{Cp}_{2}{ }^{*} \mathrm{Ru}^{(I I)}$ in the presence of protons in DCE (adapted from ref. 18). $C p_{2}{ }^{*} \mathrm{Ru}^{(I I)}$ is a weak reductant, requiring photoactivation of the hydride to reduce organic solubilised protons $\left(\left[E_{\left(\mathrm{H}^{+} / 1 / 2 \mathrm{H}_{2}\right)}^{0^{\prime}}\right]^{\mathrm{DCE}}=0.58 \mathrm{~V}\right.$ (vs. SHE) $)$.

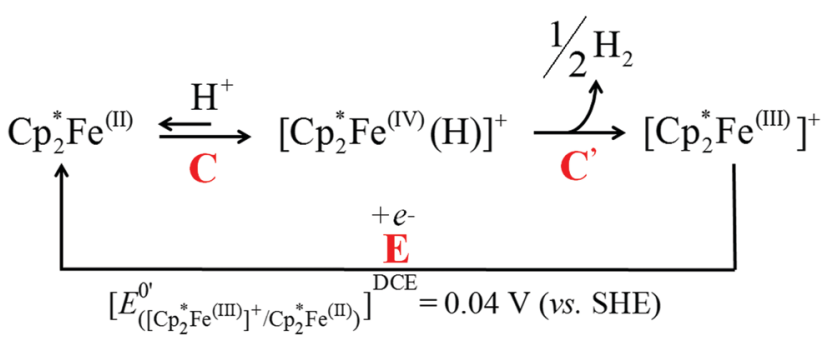

Scheme 3 Mechanism of the catalytic Electrochemical, Chemical, Chemical $\left(E C C^{\prime}\right)$ reduction of protons by $\mathrm{Cp}_{2}{ }^{*} \mathrm{Fe}^{(I I)}$ in the presence of protons in DCE. $C \mathrm{P}_{2}{ }^{*} \mathrm{Fe}^{(\mathrm{II})}$ is a strong enough reductant to reduce organic solubilised protons $\left(\left[E_{\left(\mathrm{H}^{+} / 1 / 2 \mathrm{H}_{2}\right)}^{0^{\prime}}\right]^{\mathrm{DCE}}=0.58 \mathrm{~V}(v s\right.$. SHE $\left.)\right)$ without the need for photactivation.

cathodic compartment to facilitate the photo-driven HER in the organic phase. Electrons released during the WOR are shuttled to the anode via the $\mathrm{Co}^{(\mathrm{III})} / \mathrm{Co}^{(\mathrm{II})}$ redox species and used to regenerate the oxidised $\left[\mathrm{Cp}_{2}{ }^{*} \mathrm{Ru}{ }^{(I I I)}\right]^{+}$species at the cathode. As discussed vide infra, matching the redox potentials of the redox species in both H-cell compartments is of the upmost importance. The electrochemical driving force required to drive water-splitting is provided from renewable sources and overpotentials at the cathode and anode are minimised by incorporating light-driven elements into both biphasic reactions.

Herein, the aim is to develop an electrolysis H-cell prototype to highlight the feasibility of using biphasic chemistry to achieve the cathodic HER half-reaction. The purpose is to optimise the general chemistry underpinning the use of metallocenes in such an H-cell. Thus, the biphasic HER was carried out with wellcharacterised decamethylferrocene $\left(\mathrm{Cp}_{2}{ }^{*} \mathrm{Fe}^{(\mathrm{II})}\right)$ via an $\mathrm{ECC}^{\prime}$ mechanism (Scheme 3). Ultimately, $\mathrm{Cp}_{2}{ }^{*} \mathrm{Fe}{ }^{(\mathrm{II})}$ will not be suitable for the final biphasic electrolysis design as the driving force for the reaction is purely electrochemical and, thus, presents no advantage in comparison to electrolysis in aqueous solutions. However, lessons learned with this model system are vital to inform the design of the energy efficient biphasic photo-electrolysis cells incorporating $\mathrm{Cp}_{2}{ }^{*} \mathrm{Ru}^{(\mathrm{II})}$.

\section{Experimental methods}

\section{Chemicals}

All chemicals were used as received. All aqueous solutions were prepared with ultra pure water (Millipore Milli-Q, specific resistivity 18.2 $\mathrm{M} \Omega \mathrm{cm}$ ). The solvents used were 1,2-dichloroethane (DCE, $\geq 99.8 \%$, Fluka), dichloromethane (DCM, $\geq 99.5 \%$, Sigma-Aldrich), 
acetonitrile ( $\geq 99.8 \%$, Sigma-Aldrich), diethyl ether $\left(\mathrm{Et}_{2} \mathrm{O}, \geq 99 \%\right.$, Sigma-Aldrich), hydrochloric acid ( $\mathrm{HCl}, 37 \%$, Merck) and sulfuric acid $\left(\mathrm{H}_{2} \mathrm{SO}_{4}, 98 \%\right.$, Merck). Decamethylferrocence $\left(\mathrm{Cp}_{2}{ }^{*} \mathrm{Fe}^{(\mathrm{II})}\right.$, 99\%) and ferrocene $\left(\mathrm{Cp}_{2} \mathrm{Fe}^{(\mathrm{II})}, 99 \%\right)$ were purchased from Alfa Aesar. Molybendum carbide $\left(\mathrm{Mo}_{2} \mathrm{C}, \sim 325\right.$ mesh, $\left.\geq 99.5 \%\right)$, silver nitrate $\left(\mathrm{AgNO}_{3}, \geq 99 \%\right)$, type II $3.5 \mathrm{~mm}$ silica gel beads, tetrabutylammonium hexafluorophosphate $\left(\mathrm{TBAPF}_{6}, \geq 97 \%\right.$ ), tetrahexylammonium tetrafluoroborate $\left(\mathrm{THxABF}_{4}, \geq 97 \%\right)$, sodium sulfate $\left(\mathrm{Na}_{2} \mathrm{SO}_{4}, \geq 99 \%\right)$, bis(triphenylphosphoranylidene) ammonium chloride (BACl, 97\%) and the Nafion ${ }^{\circledR}$ perfluorintaed membrane (Nafion ${ }^{\circledR} 117$, thickness 0.007 in.) were purchased from Sigma-Aldrich. Lithium tetrakis(pentafluorophenyl)borate diethyletherate $\left(\left[\mathrm{Li}\left(\mathrm{OEt}_{2}\right)_{2}\right] \mathrm{TB}\right)$ was received from Boulder Scientific Company.

BACl and $\left[\mathrm{Li}\left(\mathrm{OEt}_{2}\right)_{2}\right] \mathrm{TB}$ were used to prepare bis(triphenylphosphoranylidene) ammonium tetrakis(pentafluorophenyl)borate (BATB) by metathesis of equimolar solutions of BACl and $\left[\mathrm{Li}\left(\mathrm{OEt}_{2}\right)\right] \mathrm{TB}$ in a methanol-water $(2: 1 \mathrm{v} / \mathrm{v})$ mixture. The resulting precipitates were filtered, washed and recrystallised from acetone. The synthetic procedures to prepare dry powders of the strong organic tetrakis(pentafluorophenyl)borate diethyl etherate acid $\left(\left[\mathrm{H}\left(\mathrm{OEt}_{2}\right)_{2}\right] \mathrm{TB}\right)$ and the decamethylferrocenium cation $\left(\left[\mathrm{Cp}_{2}{ }^{*} \mathrm{Fe}^{(\mathrm{III})}\right] \mathrm{TB}\right)$ are described in detail in the ESI $\dagger$ (ESI-1).

\section{Electrochemical measurements}

All electrochemical measurements were performed in organic media, namely DCE, with either $100 \mathrm{mM} \mathrm{THxABF}_{4}, 100 \mathrm{mM}$ TBAPF $_{6}$ or $100 \mathrm{mM}$ BATB as the organic supporting electrolyte salt. Thus, to facilitate these measurements it was essential to prepare a robust $\mathrm{Ag}^{+} / \mathrm{Ag}$ double-junction organic reference electrode (DJ-ORE) capable of operating in solvents, such as DCE, that damage typical Vycor ${ }^{\circledR}$ tips and polyolefin tubing. Previously, Vycor ${ }^{\mathbb{R}}$ was successfully replaced by porous silica gel beads (type II $3.5 \mathrm{~mm}$ silica gel beads from Sigma-Aldrich, typically used for desiccation) by Vrubel et al. ${ }^{19}$ These silica gel beads require pretreatment steps if the reference electrode is used in an aqueous solution. However, herein with organic solutions, the silica gel beads did not need to be pre-treated and were directly attached to the electrode. When the organic reference solutions were inserted into the electrode the silica gel beads became "wet". Once this occurred it was essential that they were not left to dry out at any stage or else they would crack. A detailed description of how to construct the DJ-ORE is provided in the in the ESI $\dagger$ (ESI-1).

Electrochemical measurements to determine the onset potential of the $\mathrm{H}_{2}$ evolution reaction (HER) at the surface of a glassy carbon electrode (geometric area of $0.264 \mathrm{~cm}^{2}$ ) in DCE were carried out in a three-electrode configuration, with a Pt wire as the counter electrode and the organic DJ-ORE discussed above as the reference electrode. Cyclic voltammetry (CV) measurements were obtained using a PGSTAT 30 potentiostat (Metrohm, CH), under anaerobic conditions in a glovebox and using degassed DCE solutions.

The electrolysis H-cell prototype is shown in Fig. 1. Further images of the H-cell are provided in Fig. S1 and ESI-1, ESI. $\dagger$ This experimental setup allowed the continuous measurement of the UV/vis spectra of the organic phase in situ as a set potential was applied to the glassy carbon working electrode
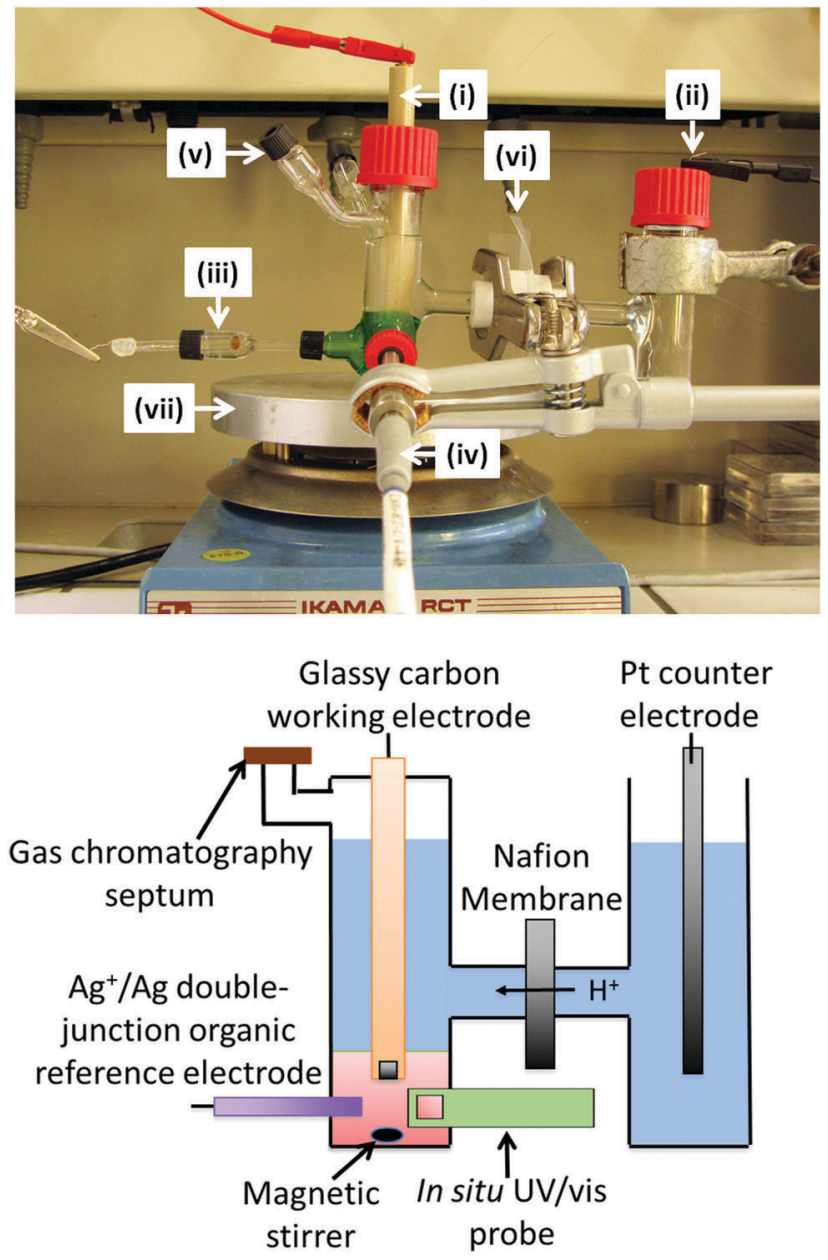

Fig. 1 The biphasic electrolysis $\mathrm{H}$-cell: (i) glassy carbon working electrode, (ii) Pt counter electrode, (iii) $\mathrm{Ag}^{+} / \mathrm{Ag}$ double-junction organic reference electrode, (iv) UV/vis spectroscopy probe, (v) septum to allow sampling for gas chromatography analysis, (vi) Nafion membrane separating the working (left) and counter electrode (right) compartments, \& (vii) magnetic stirring plate.

during chronoamperometry. Post-electrolysis the head-space gas was analysed by gas chromatography. Three different biphasic electrochemical cell configurations were studied, as described in Scheme 4, probing the influence of the nature of the organic electrolyte salt and the presence of an interfacial $\mathrm{H}_{2}$ evolution catalyst on the biphasic electrolysis induced HER.

Chronoamperometry measurements with the sealed H-cell were carried out under aerobic conditions with no degassing of aqueous or organic solutions. The organic phase was stirred to enhance diffusion of the metallocene species to the glassy carbon electrode surface. Initial biphasic electrolysis experiments (data not shown) indicated that $50 \mathrm{mM}$ BATB did not provide adequate conductivity to the DCE phase to obtain high current densities. Thus, $100 \mathrm{mM}$ BATB was found to be optimal, i.e. the lowest concentration of BATB that gave large current densities.

\section{Analysis of $\mathrm{H}_{2}$ gas evolved}

Post-biphasic electrolysis, one milliliter samples of the headspace gas in the working electrode compartment were obtained 
Biphasic electrolysis cell 1

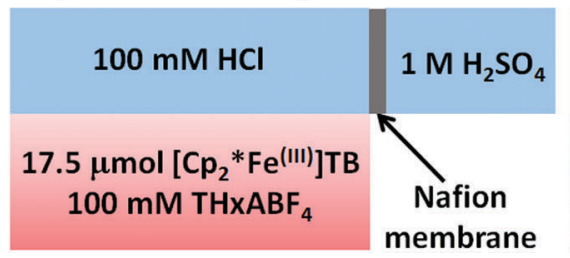

Biphasic electrolysis cell 2

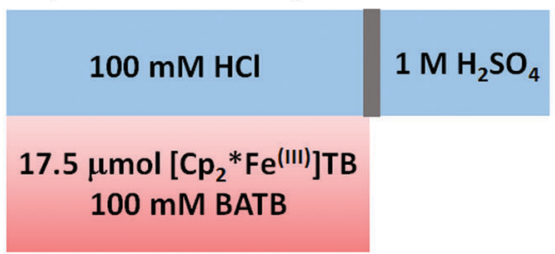

Biphasic electrolysis cell 3

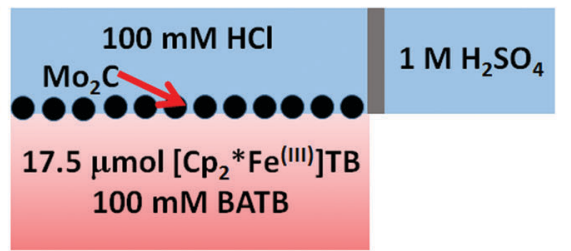

Scheme 4 Biphasic electrochemical cell configurations; the organic phase (red colour) is 1,2-dichloroethane (DCE).

using a lock-in syringe with a push-pull valve (SGE Analytical Sciences) and subsequently analysed by gas chromatography (GC) using a Perkin-Elmer GC (Clarus 400, with $5 \AA$ A molecular sieves, an $80 / 100$ mesh and a $20 \mu \mathrm{L}$ injection loop) equipped with a thermal conductivity detector (TCD). The carrier gas was argon.

\section{UV/vis spectroscopy}

$\mathrm{UV} /$ vis spectra of the decamethylferrocenium cation, $\left[\mathrm{Cp}_{2}{ }^{*} \mathrm{Fe}^{(\mathrm{III})}\right]^{+}$, were measured in situ in the DCE phase during biphasic electrolysis on an Ocean Optics CHEM2000 spectrophotometer with an Ocean Optics DH-2000-BAL balanced deuterium halogen light source. An Ocean Optics T300-UV-VIS transmission dip probe was coupled to both the light source and spectrometer with two optical fiber cables. The stainless steel probe tip is resistant to the DCE solution. Light is directed via one fiber through the open path containing the DCE solution, then is reflected by a mirror and redirected back to a receiver fiber that returns the light to the spectrometer. The total path length was $10 \mathrm{~mm}$. UV/vis scans were taken at regular intervals over a period of 22 hours. A molar extinction coefficient $(\varepsilon)$ of $\left[\mathrm{Cp}_{2}{ }^{*} \mathrm{Fe}^{(\mathrm{III})}\right]^{+}$in DCE $\left(\lambda_{\max }=779 \mathrm{~nm}\right)$ was determined previously to be $0.632 \mathrm{mM}^{-1} \mathrm{~cm}^{-1} \cdot{ }^{20}$

\section{Results and discussion}

Matching the redox potentials of the lipophilic mediators in the anodic and cathodic compartment of the biphasic electrolysis H-cell to achieve efficient electrolysis

The concept of mediated water splitting by electrolysis using an $\mathrm{H}$-cell incorporating biphasic systems, as described in Scheme 1, can be summarised by the following set of equations:

Anodic light-driven biphasic water oxidation reaction (WOR): ${ }^{9}$

$$
\begin{aligned}
& h \nu \\
& \mathrm{H}_{2} \mathrm{O}_{(\mathrm{w})} \stackrel{\mathrm{BiVO}_{4}(\text { int. })}{\longrightarrow} 2 \mathrm{H}_{(\mathrm{w})}^{+}+1 / 2 \mathrm{O}_{2(\mathrm{~g})}+2 \mathrm{e}^{-} \\
& 2\left[\mathrm{Co}^{(\mathrm{III})}(\mathrm{bpy})_{3}\right]_{(\mathrm{o})}^{3+}+2 \mathrm{e}^{-} \rightarrow 2\left[\mathrm{Co}^{(\mathrm{III})}(\mathrm{bpy})_{3}\right]_{(\mathrm{o})}^{2+}
\end{aligned}
$$

Cathodic light-driven biphasic hydrogen evolution reaction (HER): ${ }^{13,18}$

$$
\begin{gathered}
2 \mathrm{H}_{(\mathrm{w})}^{+} \stackrel{\mathrm{IT}}{\longrightarrow} 2 \mathrm{H}_{(\mathrm{o})}^{+} \\
2 \mathrm{H}_{(\mathrm{o})}^{+}+2 \mathrm{Cp}_{2}{ }^{*} \mathrm{Ru}_{(\mathrm{o})}^{(\mathrm{II})} \stackrel{h \nu}{\longrightarrow} \mathrm{H}_{2(\mathrm{~g})}+2\left[\mathrm{Cp}_{2}{ }^{*} \mathrm{Ru}^{(\mathrm{III})}\right]_{(\mathrm{o})}^{+}
\end{gathered}
$$

Regeneration of the lipophilic electron acceptor and donor species:

$$
\begin{gathered}
2\left[\mathrm{Co}^{(\mathrm{II})}(\mathrm{bpy})_{3}\right]_{(\mathrm{o})}^{2+}+2\left[\mathrm{Cp}_{2}{ }^{*} \mathrm{Ru}^{(\mathrm{III})}\right]_{(\mathrm{o})}^{+} \\
\quad \rightarrow 2\left[\mathrm{Co}^{(\mathrm{III})}(\mathrm{bpy})_{3}\right]_{(\mathrm{o})}^{3+}+2 \mathrm{Cp}_{2}{ }^{*} \mathrm{Ru}_{(\mathrm{o})}^{(\mathrm{II})}
\end{gathered}
$$

where (w), (o), (g) and (int.) denote the aqueous phase, organic phase, gaseous phase and liquid-liquid interface, respectively. IT means "ion transfer".

To maximise the efficiency of this system it is critical that the reversible redox couples in the anodic and cathodic compartments can regenerate each other spontaneously (from a thermodynamic viewpoint) as described by eqn (5). In other words, it would be ideal if no, or an absolute minimum, additional external electrochemical driving force (from renewable resources as described in Scheme 1) need be applied to drive the reduction of $\left[\mathrm{Cp}_{2}{ }^{*} \mathrm{Ru}^{(\mathrm{III})}\right]_{(\mathrm{o})}^{+}$by $\left[\mathrm{Co}^{(\mathrm{III})}(\mathrm{bpy})_{3}\right]_{(\mathrm{o})}^{2+}$. The possibility of the latter is determined by their formal reduction potentials in the oil phase. Thus, the formal reduction potential of the reversible electron acceptor $\left[\mathrm{Co}^{(\mathrm{III})}(\mathrm{bpy})_{3}\right]^{3+} /\left[\mathrm{Co}^{(\mathrm{II})}(\mathrm{bpy})_{3}\right]^{2+}$ redox couple was determined in DCE, see Fig. 2.

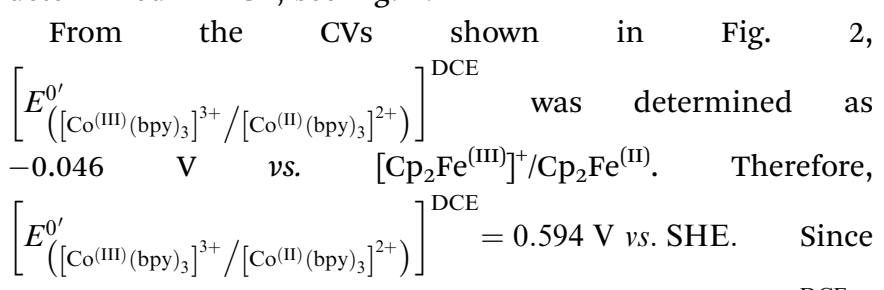
the latter is more negative than $\left[E_{\left(\left[\mathrm{Cp}_{2}{ }^{*} \mathrm{Ru}^{(\mathrm{III})}\right]^{+} / \mathrm{Cp}_{2}{ }^{*} \mathrm{Ru}^{(\mathrm{III})}\right)}\right]^{\mathrm{DCE}}=$ $0.750 \mathrm{~V}$ vs. SHE (see Table 1), $\left[\mathrm{Co}^{(\mathrm{II})}(\mathrm{bpy})_{3}\right]^{2+}$ can spontaneously reduce $\left[\mathrm{Cp}_{2}{ }^{*} \mathrm{Ru}^{(\mathrm{III})}\right]^{+}$as described in eqn (5).

\section{Proof-of-concept biphasic electrolysis experiments}

Initially, in the cathodic compartment of the H-cell, the reversible electron donor was present $100 \%$ in its oxidised form $\left[\mathrm{Cp}_{2}{ }^{*} \mathrm{Fe}^{(\mathrm{III})}\right]^{+}$; synthesised with a tetrakis(pentafluorophenyl)borate counter anion $\left(\mathrm{TB}^{-}\right)$. During biphasic electrolysis a sufficiently negative potential was applied to the glassy carbon working electrode to reduce $\left[\mathrm{Cp}_{2}{ }^{*} \mathrm{Fe}^{(\mathrm{III})}\right]^{+}$to $\mathrm{Cp}_{2}{ }^{*} \mathrm{Fe}^{(\mathrm{II})}$ (using electrons released from the WOR at the platinum electrode in the anodic compartment), but not so negative as to induce direct $\mathrm{H}_{2}$ evolution at the working electrode surface. This precise potential was determined by cyclic voltammetry in acidified DCE solutions containing $\left[\mathrm{Cp}_{2}{ }^{*} \mathrm{Fe}^{(\mathrm{III})}\right]^{+}$as $-1.164 \mathrm{~V}$ vs. $\left[\mathrm{Cp}_{2} \mathrm{Fe}^{(\mathrm{IIII}}\right]^{+} / \mathrm{Cp}_{2} \mathrm{Fe}^{(\mathrm{II})}\left(\mathrm{Cp}=\mathrm{C}_{5} \mathrm{H}_{5}\right)$, 


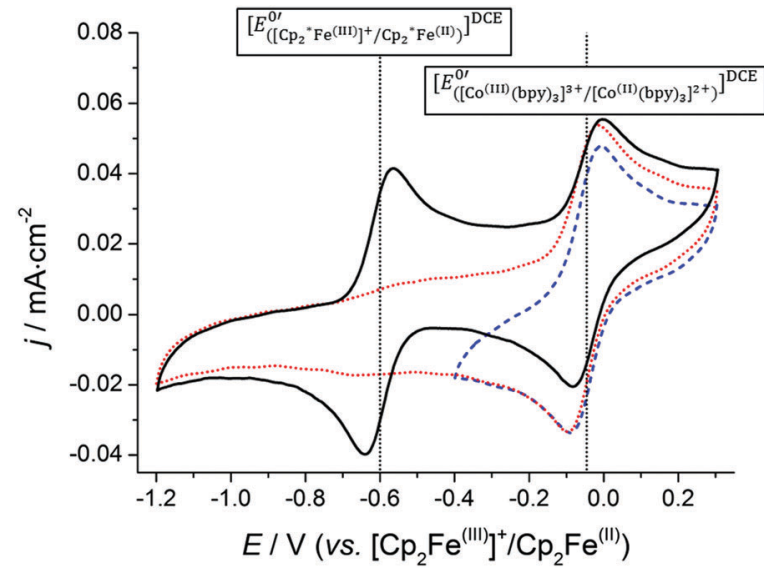

Fig. 2 Cyclic voltammograms (CVs) of the reversible $\left[\mathrm{Co}^{(\mathrm{IIII})}(\mathrm{bpy})_{3}\right]^{3+} /$ $\left[\mathrm{Co}^{(I I)}(\mathrm{bpy})_{3}\right]^{2+}$ redox couple in DCE. All CVs were calibrated versus the $\left[\mathrm{Cp}_{2} \mathrm{Fe}^{(I I I)}\right]^{+} / \mathrm{Cp}_{2} \mathrm{Fe}^{(I I)}$ redox couple by using the $\left[\mathrm{Cp}_{2}{ }^{*} \mathrm{Fe} \mathrm{F}^{(I I I)}\right]^{+} / \mathrm{Cp}_{2}{ }^{*} \mathrm{Fe}^{(\mathrm{II})}$ redox couple as an internal calibrant. The formal reduction potential of the latter is $-0.600 \mathrm{~V}$ vs. $\left[\mathrm{Cp}_{2} \mathrm{Fe}^{(\mathrm{IIII})}\right]^{+} / \mathrm{Cp}_{2} \mathrm{Fe}^{(\mathrm{III})}$ (see Table 1 ). The black CV is of $0.1 \mathrm{mM}\left[\mathrm{Co}^{(I I)}(\mathrm{bpy})_{3}\right] \mathrm{TB}_{2}$ and $0.1 \mathrm{mM} \mathrm{Cp}_{2}{ }^{*} \mathrm{Fe}^{(\text {(II) }}$. The blue and red CVs are of $0.1 \mathrm{mM}\left[\mathrm{Co}^{(I I)}(\mathrm{bpy})_{3}\right] \mathrm{TB}_{2}$ only recorded over shorter and longer polarisable potential windows, respectively. The organic supporting electrolyte was $100 \mathrm{mM} \mathrm{TBAPF}_{6}$. All CVs were obtained under anaerobic conditions, using degassed DCE solutions, in a glovebox and at a scan rate of $50 \mathrm{mV} \mathrm{s}^{-1}$. Glassy carbon and platinum disc electrodes were used as the working and counter electrodes respectively, while the reference electrode was a $\mathrm{Ag}^{+} / \mathrm{Ag}$ DJ-ORE.

Fig. S2 and ESI-3, ESI. $\dagger$ On top of the organic phase was an acidified aqueous solution. Consequently, to maintain electroneutrality of the organic phase upon reduction of $\left[\mathrm{Cp}_{2}{ }^{*} \mathrm{Fe}^{(\mathrm{III})}\right]^{+}$, either a cation must transfer from water to DCE, or an anion from DCE to water. During biphasic $\mathrm{H}_{2}$ evolution the former occurs with a proton undergoing FIT to form the hydride species, $\left[\mathrm{Cp}_{2}{ }^{*} \mathrm{Fe}^{(\mathrm{IV})}(\mathrm{H})\right]^{+}$. Thus, the organic electrolyte anion must have a more positive formal ion transfer potential from water to DCE $\left(\Delta \phi_{\mathrm{tr}, \mathrm{i}}^{0^{\prime}, \mathrm{w} \rightarrow \mathrm{DCE}}\right)$ than that of a proton (i.e., more energy is required to transfer the anion from DCE to water than the proton from water to DCE). To highlight the critical role of the organic electrolyte anion in achieving biphasic $\mathrm{H}_{2}$ evolution in the cathodic compartment, two biphasic electrolysis cells were tested (Scheme 4); cell 1 with tetrahexylammonium tetrafluoroborate $\left(\mathrm{THxABF}_{4}\right)$ and cell 2 with bis(triphenylphosphoranylidene) ammonium tetrakis(pentafluorophenyl)borate (BATB) as the organic electrolyte.

$\Delta \phi_{\mathrm{tr} . \mathrm{i}}^{0^{\prime}, \mathrm{w} \rightarrow \mathrm{DCE}}$ values for all aqueous and organic electrolyte ions studied, and also $\left[\mathrm{Cp}_{2}{ }^{*} \mathrm{Fe}^{(\mathrm{III})}\right]^{+}$, are summarised in Table 2. $\mathrm{BF}_{4}{ }^{-}$has a less positive $\Delta \phi_{\mathrm{tr}, \mathrm{i}}^{0^{\prime}, \mathrm{w} \rightarrow \mathrm{DCE}}$ than a proton. Thus, during biphasic electrolysis no protons were transferred from water to DCE, $\left[\mathrm{Cp}_{2}{ }^{*} \mathrm{Fe}^{(\mathrm{IV})}(\mathrm{H})\right]^{+}$was not formed, and consequently no $\mathrm{H}_{2}$ evolved. The latter also means $\left[\mathrm{Cp}_{2}{ }^{*} \mathrm{Fe}^{(\mathrm{III})}\right]^{+}$cannot be regenerated (Scheme 5(A)). The complete conversion of $\left[\mathrm{Cp}_{2}{ }^{*} \mathrm{Fe}^{(\mathrm{III})}\right]^{+}$to $\mathrm{Cp}_{2}{ }^{*} \mathrm{Fe}^{(\mathrm{II})}$ was demonstrated by chronoamperometry with the current density at the electrode (corresponding to the reduction of $\left.\left[\mathrm{Cp}_{2}{ }^{*} \mathrm{Fe}^{(\mathrm{III})}\right]^{+}\right)$approaching zero after 3 hours of electrolysis (Fig. 3A, black trace). Furthermore, total charge passed $(Q=1.688 \mathrm{C})$
Table 2 Summary of the formal Gibbs energies of transfer $\left(\Delta G_{\mathrm{tr}, \mathrm{i}}^{0^{\prime}, \mathrm{w} \rightarrow \mathrm{DCE}}\right)$ and the formal ion transfer potentials $\left(\Delta \phi_{\mathrm{tr}, \mathrm{i}}^{0^{\prime}, \mathrm{DCE}}\right)$ from water to DCE for each electrolyte ion studied, and also $\left[\mathrm{Cp}_{2}{ }^{*} \mathrm{Fe}^{(\mathrm{IIII})}\right]^{+}$. Note that the relationship between $\Delta G_{\mathrm{tr}, \mathrm{i}}^{0^{\prime}, \mathrm{w} \rightarrow \mathrm{DCE}}$ and $\Delta \phi_{\mathrm{tr}, \mathrm{i}}^{0^{\prime}, \mathrm{w} \rightarrow \mathrm{DCE}}$ is $\Delta G_{\mathrm{tr}, \mathrm{i}}^{0^{0}, \mathrm{w} \rightarrow \mathrm{DCE}}=z_{\mathrm{i}} F \Delta \phi_{\mathrm{tr}, \mathrm{i}}^{0^{\prime}, \mathrm{w} \rightarrow \mathrm{DCE}}$ where $z_{\mathrm{i}}$ is the charge of the cation or anion undergoing ion transfer across the water-organic interface

\begin{tabular}{lrcc}
\hline Ion & $\Delta G_{\mathrm{tr}, \mathrm{i}}^{0^{\prime}, \mathrm{i} \rightarrow \mathrm{DCE}}\left(\mathrm{kJ} \mathrm{mol}^{-1}\right)$ & $\Delta \phi_{\mathrm{tr}, \mathrm{i}}^{0^{\prime}, \mathrm{W} \rightarrow \mathrm{DCE}}(\mathrm{V})$ & Ref. \\
\hline $\mathrm{TB}^{-}$ & -68.5 & 0.710 & 26 \\
$\mathrm{H}^{+}$ & 56.0 & 0.580 & 26 \\
$\mathrm{BF}_{4}^{-}$ & 17.9 & 0.186 & 27 \\
{$\left[\mathrm{Cp}_{2} \mathrm{Fe}^{(\mathrm{IIII})}\right]^{+}$} & -25.1 & -0.260 & 28 \\
$\mathrm{THxA}^{+}$ & -45.3 & -0.470 & 26 \\
$\mathrm{Cl}^{-}$ & 51.1 & -0.530 & 26 \\
$\mathrm{BA}^{+}$ & -67.5 & -0.700 & 26
\end{tabular}

precisely matched the quantity of charge required to fully convert $17.5 \mu \mathrm{mol}$ of $\left[\mathrm{Cp}_{2}{ }^{*} \mathrm{Fe}^{(\mathrm{III})}\right]^{+}$present to $\mathrm{Cp}_{2}{ }^{*} \mathrm{Fe}^{(\mathrm{II})}$ (Fig. 3(B), black trace). Finally, the UV/vis absorbance signal for $\left[\mathrm{Cp}_{2}{ }^{*} \mathrm{Fe}^{(\mathrm{III})}\right]^{+}$ at $779 \mathrm{~nm}$ completely disappeared after 3 hours (Fig. 3(C), black trace) and no $\mathrm{H}_{2}$ was detected by GC in the head-space of the cathodic compartment post-biphasic electrolysis (Fig. S3 and ESI-4, ESI $\dagger$ ).

The organic anion $\mathrm{TB}^{-}$has a more positive $\Delta \phi_{\mathrm{tr}, \mathrm{i}}^{0^{\prime}, \mathrm{w} \rightarrow \mathrm{DCE}}$ than a proton. Thus, during biphasic electrolysis protons are transferred from water to DCE, $\left[\mathrm{Cp}_{2}{ }^{*} \mathrm{Fe}^{(\mathrm{IV})}(\mathrm{H})\right]^{+}$is formed, $\mathrm{H}_{2}$ evolved and $\left[\mathrm{Cp}_{2}{ }^{*} \mathrm{Fe}^{(\mathrm{III})}\right]^{+}$regenerated (Scheme $5(\mathrm{~B})$ ). Two plateaus in the current density were observed during electrolysis (Fig. 3(A), blue trace). As the aqueous and organic solutions were not degassed before sealing the biphasic electrolysis cell, $\mathrm{O}_{2}$ was present upon commencing electrolysis. Thus, the plateau covering the initial 3 hours represents proton reduction in DCE via $\mathrm{Cp}_{2}{ }^{*} \mathrm{Fe}^{(\mathrm{II})}$ to $\mathrm{H}_{2} \mathrm{O}_{2}$, and not $\mathrm{H}_{2}$, as discussed previously. ${ }^{21}$ Once all $\mathrm{O}_{2}$ was converted to $\mathrm{H}_{2} \mathrm{O}_{2}$, a new plateau was observed until electrolysis ceased representing subsequent proton reduction to $\mathrm{H}_{2}$. The reduction of $\mathrm{O}_{2}$ to $\mathrm{H}_{2} \mathrm{O}_{2}$ is thermodynamically more favourable than $\mathrm{H}_{2}$ evolution in DCE. ${ }^{14,21-25}$ Thus, kinetically the rate of $\mathrm{H}_{2} \mathrm{O}_{2}$ formation far exceeds that of $\mathrm{H}_{2}$ evolution (especially in the absence of a $\mathrm{H}_{2}$ evolution catalyst). Accordingly, during $\mathrm{H}_{2} \mathrm{O}_{2}$ formation, $\left[\mathrm{Cp}_{2}{ }^{*} \mathrm{Fe}^{(\mathrm{III})}\right]^{+}$was regenerated at a much faster rate as reflected in the higher current densities (Fig. 3A, blue trace) and quicker accumulation of total charge passed (Fig. 3(B), blue trace) during electrolysis prior to $\mathrm{O}_{2}$ depletion. The total charge passed with $\mathrm{TB}^{-}$as the organic anion $(Q=10.505 \mathrm{C})$ indicates that, over 22 hours, each $\left[\mathrm{Cp}_{2}{ }^{*} \mathrm{Fe}^{(\mathrm{III})}\right]^{+}$molecule was consumed at the electrode and regenerated in the organic phase over 6 times. Both plateaus were again observed by UV/vis spectroscopy (Fig. 3(C), blue trace). The transition from $\mathrm{H}_{2} \mathrm{O}_{2}$ to $\mathrm{H}_{2}$ formation via $\mathrm{Cp}_{2}{ }^{*} \mathrm{Fe}^{(\mathrm{II})}$ is clearly evident, and the rapid kinetics of $\mathrm{H}_{2} \mathrm{O}_{2}$ formation and $\left[\mathrm{Cp}_{2}{ }^{*} \mathrm{Fe}^{(\mathrm{III})}\right]^{+}$regeneration were indicated by a marginal dip in absorbance (approximately 4 to $8 \%$ ) initially. Finally, $\mathrm{H}_{2}$ was detected by GC in the headspace of the cathodic compartment post-biphasic electrolysis (Fig. S3 and ESI-4, ESI $\dagger$ ).

The kinetics of biphasic $\mathrm{H}_{2}$ evolution via $\mathrm{Cp}_{2}{ }^{*} \mathrm{Fe}^{(\mathrm{II})}$ can be dramatically improved by either generating $\mathrm{H}_{2}$ evolution catalysts in situ at the interface (e.g., by reducing aqueous soluble 
(A)

Biphasic electrolysis cell 1

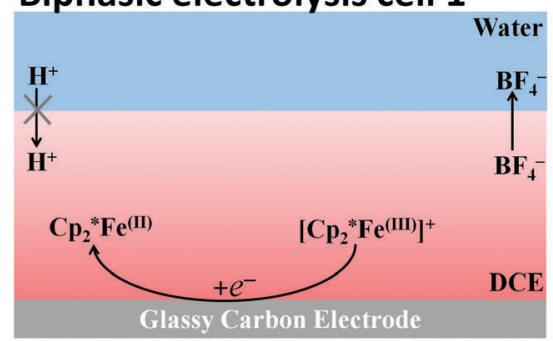

(B) Biphasic electrolysis cell 2

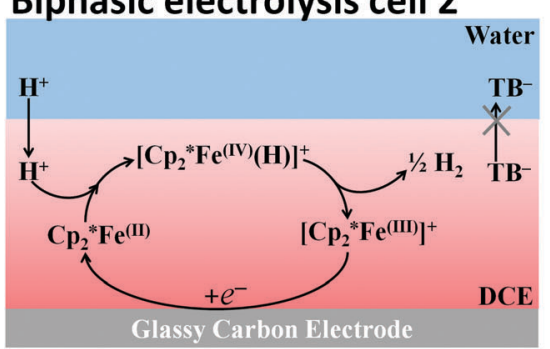

(C)

Biphasic electrolysis cell 3

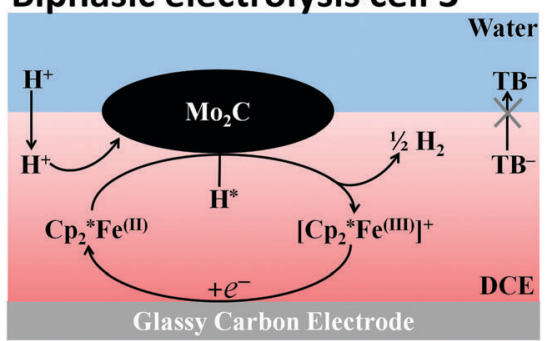

Scheme 5 Mechanisms taking place in the three biphasic electrolysis cells investigated, highlighting (i) the critical role of the organic electrolyte anion on the ability to recycle the $\left[\mathrm{Cp}_{2}{ }^{*} \mathrm{Fe} \mathrm{e}^{(I I I)}\right]^{+} / \mathrm{Cp}_{2}{ }^{*} \mathrm{Fe}{ }^{(I I)}$ redox couple at the glassy carbon electrode and (ii) the change in mechanism in the presence of an interfacial $\mathrm{H}_{2}$ evolution catalyst. The latter dramatically increases the rates of $\mathrm{H}_{2}$ evolution at the interface and, concomitantly, recycling of the $\left[\mathrm{Cp}_{2}{ }^{*} \mathrm{Fe}^{(\mathrm{IIII})}\right]^{+} / \mathrm{Cp}_{2}{ }^{*} \mathrm{Fe}^{(I I)}$ redox couple at the glassy carbon electrode.
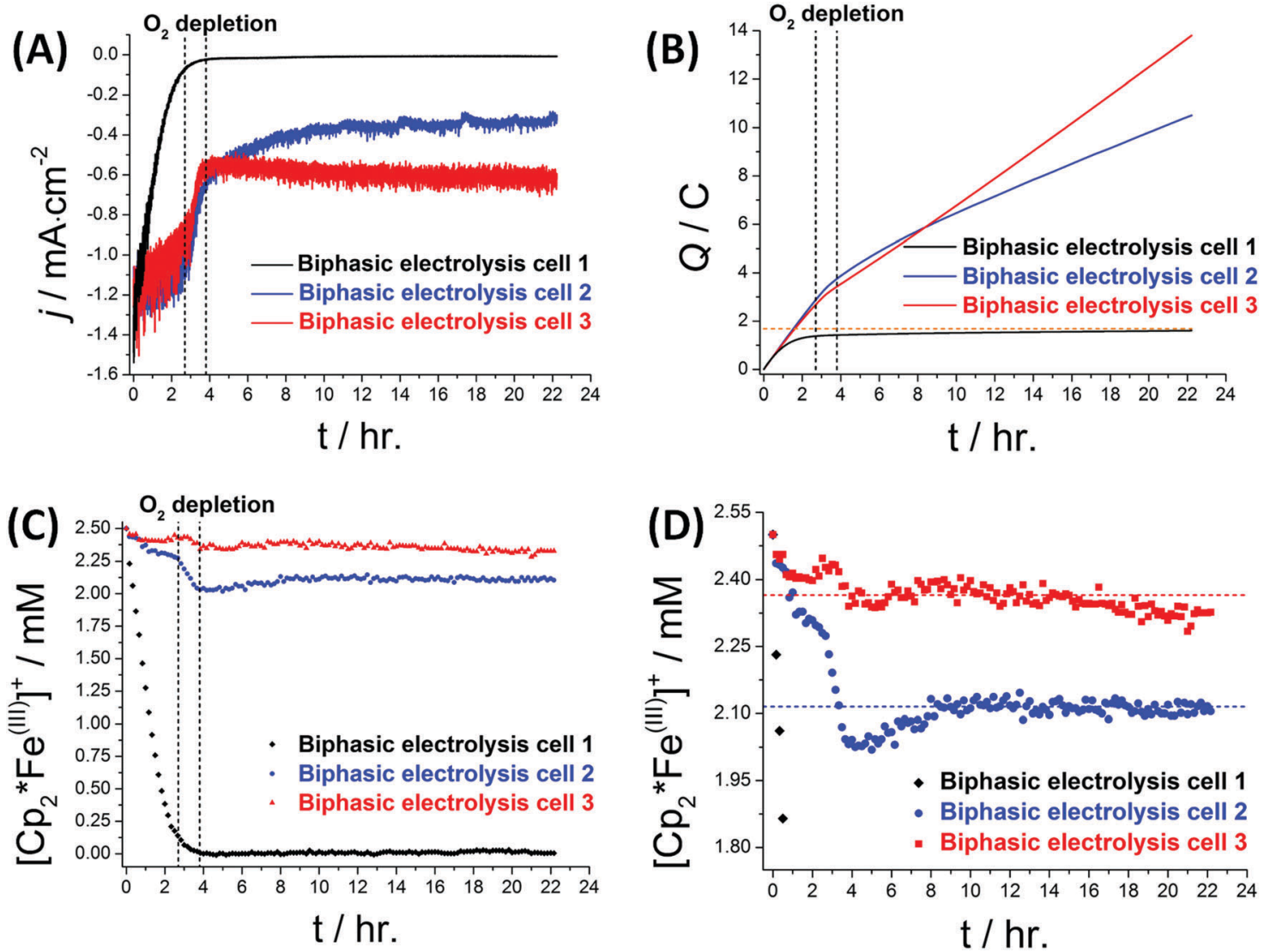

Fig. 3 In operando analysis of biphasic electrolysis of $\left[\mathrm{Cp}_{2}{ }^{*} \mathrm{Fe} \mathrm{e}^{(\mathrm{III})}\right]^{+}(n=17.5 \mu \mathrm{mol})$ in DCE, contacted with an acidic aqueous phase containing $100 \mathrm{mM}$ $\mathrm{HCl}$ in the working electrode compartment. (A) Current density $\left(\mathrm{j} / \mathrm{mA} \mathrm{cm}^{-2}\right)$ and (B) total charge passed $(Q / C)$ as a function of time for each biphasic electrochemical cell. (C and D) Monitoring changes in the UV/vis absorbance $\left(\lambda_{\max }=779 \mathrm{~nm}\right)$ for $\left[\mathrm{Cp}_{2}{ }^{*} \mathrm{Fe}^{(\mathrm{IIII})}\right]^{+}$during biphasic electrolysis. The dashed black lines in $(A-C)$ represent the time period during which dissolved $\mathrm{O}_{2}$ in the DCE phase was fully consumed. The dashed orange line in (B) represents the theoretical quantity of charge that must be passed for the complete conversion of $\left[C \mathrm{Cp}_{2}{ }^{\star} F \mathrm{e}^{(\mathrm{IIII})}\right]^{+}$to $C \mathrm{Cp}_{2}{ }^{*} \mathrm{Fe} \mathrm{e}^{(\mathrm{II})}$ in $\mathrm{DCE}(Q=z n F=1.688 \mathrm{C}$, where $z=1$ and $n=17.5 \mu \mathrm{mol}$ ), assuming $\mathrm{Cp}_{2}{ }^{*} \mathrm{Fe}^{(\mathrm{III})}$ formed does not subsequently undergo oxidation.

Pt or Pd salts at the interface in the presence of an oil-based electron donor $)^{15,29}$ or, more simply, by floating pre-formed $\mathrm{H}_{2}$ evolution catalytic nanoparticles ${ }^{20,30-39}$ or nanocomposites ${ }^{40-42}$ at the water-organic interface (Scheme 5(C)). These floating catalysts can significantly improve efficiency in terms of turnover frequency of $\left[\mathrm{Cp}_{2}{ }^{*} \mathrm{Fe}^{(\mathrm{III})}\right]^{+}$consumption/regeneration cycles.
To demonstrate the latter, biphasic electrolysis was performed with $\mathrm{Mo}_{2} \mathrm{C}$ microparticles floating at the interface and $100 \mathrm{mM}$ BATB as the organic electrolyte (cell 3, Scheme 4). $\mathrm{Mo}_{2} \mathrm{C}$ is capable of catalysing both $\mathrm{O}_{2}$ reduction and $\mathrm{H}_{2}$ evolution. ${ }^{43,44}$ As the rates of $\mathrm{O}_{2}$ reduction are already rapid with $\mathrm{Cp}_{2}{ }^{*} \mathrm{Fe}^{(\mathrm{II})}$, improvements in the rate (as indicated by higher current densities during electrolysis) 
are difficult to discern. However, after $\mathrm{O}_{2}$ depletion, the rate of $\mathrm{H}_{2}$ evolution was clearly enhanced in the presence of $\mathrm{Mo}_{2} \mathrm{C}$, with significant increases in current density (Fig. 3(A), red trace) and quicker accumulation of total charge passed (Fig. 3(B), red trace) during electrolysis in comparison to the identical experiment without $\mathrm{Mo}_{2} \mathrm{C}$ (Fig. 3(A) and (B), blue traces). The current density with $\mathrm{Mo}_{2} \mathrm{C}$ present is steady over the 22 hour period studied, indicating stability of the catalyst during biphasic electrolysis. The total charge passed with $\mathrm{Mo}_{2} \mathrm{C}$ present and $\mathrm{TB}^{-}$as the organic anion $(Q=13.801 \mathrm{C})$ indicates that, over 22 hours, each $\left[\mathrm{Cp}_{2}{ }^{*} \mathrm{Fe}^{(\mathrm{III})}\right]^{+}$molecule was recycled over 8 times. This represents a significant $25 \%$ improvement in the efficiency of biphasic electrolysis over non-catalysed conditions. UV/vis spectroscopy indicated a small improvement in the kinetics of $\mathrm{H}_{2} \mathrm{O}_{2}$ formation and major improvement in kinetics of $\mathrm{H}_{2}$ evolution with $\mathrm{Mo}_{2} \mathrm{C}$ present (Fig. 3(C), red trace). After $\mathrm{O}_{2}$ depletion, the absorbance plateau for $\left[\mathrm{Cp}_{2}{ }^{*} \mathrm{Fe}^{(\mathrm{III})}\right]^{+}$increased from $84 \%$ of the maximum possible (Fig. 3(D), blue trace) to 94\% (Fig. 3(D), red trace) for uncatalysed versus $\mathrm{Mo}_{2} \mathrm{C}$ catalysed conditions. Finally, $\mathrm{H}_{2}$ was detected by GC in the head-space of the cathodic compartment post-biphasic electrolysis (Fig. S3 and ESI-4, ESI $\dagger$ ).

\section{Determination of the interfacial Galvani potential difference $\left(\Delta_{\mathrm{o}}^{\mathrm{w}} \phi\right)$ established at the polarised water-organic interface for each biphasic electrochemical cell during electrolysis}

The UV/vis spectroscopic data provides a precise measurement of the concentration of $\left[\mathrm{Cp}_{2}{ }^{*} \mathrm{Fe}^{(\mathrm{III})}\right]^{+}$during the course of electrolysis. Thus, with this information, the concentrations of protons pumped into DCE (for cells 2 and 3 ) and $\mathrm{BF}_{4}{ }^{-}$extracted to water (for cell 1) to maintain electroneutrality upon reduction of $\left[\mathrm{Cp}_{2}{ }^{*} \mathrm{Fe}^{(\mathrm{III})}\right]^{+}$were determined. The complexation constant of $\mathrm{Cp}_{2}{ }^{*} \mathrm{Fe}^{(\mathrm{II})}$ with protons is quite small $\left(5 \times 10^{2} \mathrm{~L} \mathrm{~mol}^{-1} \mathrm{~s}^{-1}\right),{ }^{21}$ and $\left[\mathrm{Cp}_{2}{ }^{*} \mathrm{Fe}^{(\mathrm{IV})}(\mathrm{H})\right]^{+}$formation has been noted as being reversible with the weakly coordinating proton. ${ }^{21}$ Therefore, all of the missing $\left[\mathrm{Cp}_{2}{ }^{*} \mathrm{Fe}^{(\mathrm{III})}\right]^{+}$at any time $(t=x \mathrm{~s})$ during electrolysis (due to its reduction at the glassy carbon electrode) is assumed to be present as $\mathrm{Cp}_{2}{ }^{*} \mathrm{Fe}^{(\mathrm{II})}$ with effectively zero $\left[\mathrm{Cp}_{2}{ }^{*} \mathrm{Fe}^{(\mathrm{IV})}(\mathrm{H})\right]^{+}$ in the DCE. From UV/vis spectroscopy, the concentration of $\left[\mathrm{Cp}_{2}{ }^{*} \mathrm{Fe}^{(\mathrm{III})}\right]^{+}$is known both initially at $t=0 \mathrm{~s}\left(c_{\left[\mathrm{Cp}_{2}{ }^{*} \mathrm{Fe}^{(\mathrm{III})}\right]^{+}, t=0}^{\mathrm{DCE}}\right)$ and at $t=x \mathrm{~s}\left(c_{\left[\mathrm{Cp}_{2}{ }^{*} \mathrm{Fe}^{(\mathrm{III})}\right]^{+}, t=x}^{\mathrm{DCE}}\right)$, and therefore the concentration of $\mathrm{Cp}_{2}{ }^{*} \mathrm{Fe}^{(\mathrm{II})}$ present in DCE at $t=x \mathrm{~s}$ was calculated as

$$
c_{\mathrm{Cp}_{2}{ }^{*} \mathrm{Fe}^{(\mathrm{II})}, t=x}^{\mathrm{DC}}=\left(c_{\left[\mathrm{Cp}_{2}{ }^{*} \mathrm{Fe}^{(\mathrm{III})}\right]^{+}, t=0}^{\mathrm{DCE}}-c_{\left[\mathrm{Cp}_{2}{ }^{*} \mathrm{Fe}^{(\mathrm{III})}\right]^{+}, t=x}^{\mathrm{DCE}}\right)
$$

For biphasic electrochemical cells 2 and 3 with BATB electrolyte present, the concentration of protons present in DCE to maintain electroneutrality upon reduction of $\left[\mathrm{Cp}_{2}{ }^{*} \mathrm{Fe}^{(\mathrm{III})}\right]^{+}$ at $t=x \mathrm{~s}$ was calculated as

$$
c_{\mathrm{H}^{+}, t=x}^{\mathrm{DCE}}=c_{\mathrm{Cp}_{2}{ }^{*} \mathrm{Fe}^{(\mathrm{II})}, t=x}^{\mathrm{DCE}}=\left(c_{\left[\mathrm{Cp}_{2}{ }^{*} \mathrm{Fe}^{(\mathrm{III})}\right]^{+}, t=0}^{\mathrm{DC}}-c_{\left[\mathrm{Cp}_{2}{ }^{*} \mathrm{Fe}^{(\mathrm{III})}\right]^{+}, t=x}^{\mathrm{DCE}}\right)
$$

With this knowledge, the Nernst equation for ion transfer at the interface between two immiscible electrolyte solutions (ITIES) was applied to determine the interfacial Galvani potential difference $\left(\Delta_{\mathrm{o}}^{\mathrm{w}} \phi\right)$ at any particular time during electrolysis,

$$
\Delta_{\mathrm{o}}^{\mathrm{w}} \phi=\Delta \phi_{\mathrm{tr}, \mathrm{H}^{+}}^{0^{\prime}, \mathrm{W} \rightarrow \mathrm{DCE}}+\frac{R T}{F} \ln \left(\frac{c_{\mathrm{H}^{+}, t=x}^{\mathrm{DCE}}}{c_{\mathrm{H}^{+}, t=x}^{\mathrm{w}}}\right)
$$

where $\Delta \phi_{\mathrm{tr}, \mathrm{H}^{+}}^{0^{\prime}, \mathrm{WCE}}=0.580 \mathrm{~V}$ (see Table 2) and $c_{\mathrm{H}^{+}, t=x}^{\mathrm{w}}=$ $\left(c_{\mathrm{H}^{+}, t=0}^{\mathrm{w}}-c_{\mathrm{H}^{+}, t=x}^{\mathrm{DCE}}\right)$. For all experiments $c_{\mathrm{H}^{+}, t=0}^{\mathrm{w}}=100 \mathrm{mM}$. The volumes of the aqueous and organic phases in the cathodic compartment of the H-cell were approximately equal.

As discussed extensively, upon reduction of $\left[\mathrm{Cp}_{2}{ }^{*} \mathrm{Fe}^{(\mathrm{III})}\right]^{+}$during electrolysis with $\mathrm{THxABF}_{4}$ organic electrolyte, protons are not transferred to the DCE phase and instead $\mathrm{BF}_{4}{ }^{-}$is transferred to the aqueous phase. Thus, the concentration of $\mathrm{BF}_{4}{ }^{-}$remaining in DCE at $t=x \mathrm{~s}$ is

$$
\begin{aligned}
c_{\mathrm{BF}_{4}{ }^{-}, t=x}^{\mathrm{DCE}} & =\left(c_{\mathrm{BF}_{4}^{-}, t=0}^{\mathrm{DCE}}-\left(c_{\left[\mathrm{Cp}_{2}{ }^{*} \mathrm{Fe}^{(I I I)}\right]_{, t}^{+}}^{\mathrm{DCE}}-c_{\left[\mathrm{Cp}_{2}{ }^{*} \mathrm{Fe}^{(I I I)}\right]^{+}, t=x}^{\mathrm{DCE}}\right)\right) \\
& =\left(c_{\mathrm{BF}_{4}{ }^{-}, t=0}^{\mathrm{DCE}}-c_{\mathrm{Cp}_{2}^{*} \mathrm{Fe}^{(I I)}, t=x}^{\mathrm{DCE}}\right)
\end{aligned}
$$

For all experiments $c_{\mathrm{BF}_{4}^{-}, t=0}^{\mathrm{DCE}}=100 \mathrm{mM}$. Again, it is important to note that the volumes of the aqueous and organic phases in the cathodic compartment of the H-cell were approximately equal. With this knowledge $\Delta_{\mathrm{o}}^{\mathrm{w}} \phi$ for biphasic electrochemical cell 1 was calculated by applying the Nernst equation for $\mathrm{BF}_{4}{ }^{-}$ ion transfer as follows,

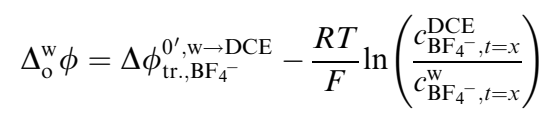

where $\Delta \phi_{\mathrm{tr}^{\prime}, \mathrm{BF}_{4}^{-}}^{0^{\prime}, \mathrm{WCE}}=0.186 \mathrm{~V}$ (see Table 1) and $c_{\mathrm{BF}_{4}^{-}, t=x}^{\mathrm{DCE}}=$ $\left(c_{\mathrm{BF}_{4}^{-}, t=0}^{\mathrm{DCE}}-c_{\mathrm{BF}_{4}^{-}, t=x}^{\mathrm{DCE}}\right) \cdot \Delta_{\mathrm{o}}^{\mathrm{w}} \phi$ was plotted versus time for each of the three biphasic electrochemical cells studied in Fig. 4.

The positive polarization of the water-organic interface to 0.441 and $0.411 \mathrm{~V}$ for cells 2 and 3, respectively, with the exceptionally hydrophobic $\mathrm{TB}^{-}$organic electrolyte anion induced proton transfer from water to DCE. On the other hand, with cell 1 and the less hydrophobic $\mathrm{BF}_{4}{ }^{-}$organic electrolyte anion,

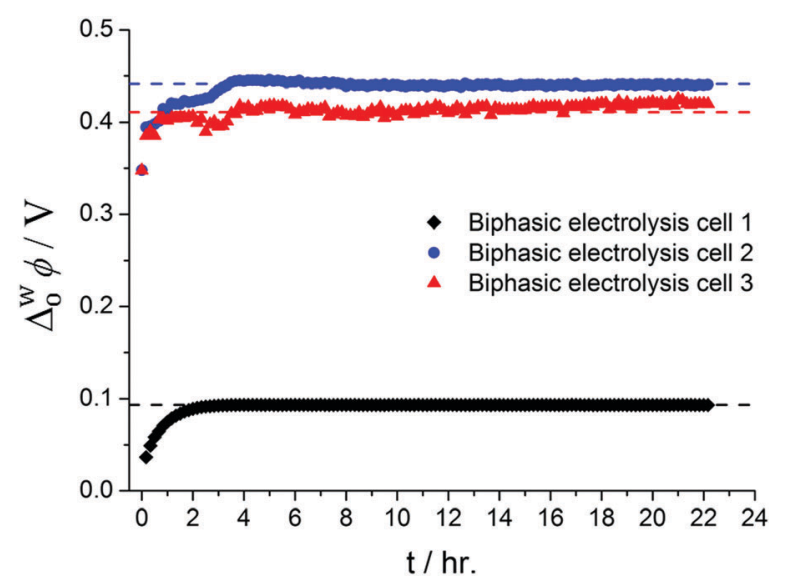

Fig. 4 Variation of the interfacial Galvani potential difference $\left(\Delta_{\circ}^{w} \phi\right)$ at the polarised water-organic interface during biphasic electrolysis. 
the moderate positive polarization of $0.093 \mathrm{~V}$ was not sufficient to induce any proton transfer considering $\Delta \phi_{\mathrm{tr} ., \mathrm{H}^{+}}^{0^{\prime}, \mathrm{WCE}}=0.580 \mathrm{~V}$ (see Table 2).

Determination of the Nernst potential established in the organic phase for each biphasic electrochemical cell during electrolysis: evidence of redox electrocatalysis by floating $\mathrm{Mo}_{2} \mathrm{C}$

The Nernst potential in the organic phase versus the standard hydrogen electrode (SHE) at any particular time during electrolysis was determined as follows,

$$
\begin{aligned}
& {\left[E_{\left[\mathrm{Cp}_{2}{ }^{*} \mathrm{Fe}^{(I I I)}\right]^{+} / \mathrm{Cp}_{2}{ }^{*} \mathrm{Fe}^{(\mathrm{II})}}^{\mathrm{Nenst}}\right]_{\mathrm{SHE}}^{\mathrm{DCE}}=\left[E_{\left[\mathrm{Cp}_{2}{ }^{0^{\prime}} \mathrm{Fe}^{(\mathrm{III})}\right]^{+} / \mathrm{Cp}_{2}{ }^{*} \mathrm{Fe}^{(\mathrm{II})}}^{{ }^{\prime}}\right]_{\mathrm{SHE}}^{\mathrm{DCE}}} \\
& +\frac{R T}{F} \ln \left(\frac{c_{\left[\mathrm{Cp}_{2}{ }^{*} \mathrm{Fe}^{(I I I)}\right]^{+}, t=x}^{\mathrm{DCE}}}{c_{\mathrm{Cp}_{2}{ }^{*} \mathrm{Fe}^{(\mathrm{III})}, t=x}}\right)
\end{aligned}
$$

and plotted versus time for each of the three biphasic electrochemical cells studied in Fig. 5. $\left[E_{\left[\mathrm{Cp}_{2}{ }^{*} \mathrm{Fe}^{(\mathrm{III})}\right]^{+} / \mathrm{Cp}_{2}{ }^{*} \mathrm{Fe}^{(\mathrm{II})}}^{0^{\prime}}\right]_{\mathrm{SHE}}^{\mathrm{DCE}}=0.04 \mathrm{~V} v$. SHE, ${ }^{15}$ see Table 1.

$\left[E_{\left[\mathrm{Cp}_{2}{ }^{*} \mathrm{Fe}^{(I I I)}\right]^{+} / \mathrm{Cp}_{2}{ }^{*} \mathrm{Fe}^{(\mathrm{III})}}^{\mathrm{Nerns}}\right]_{\mathrm{SHE}}^{\mathrm{DCE}}$ depends only on the ratio of $\left[\mathrm{Cp}_{2}{ }^{*} \mathrm{Fe}^{(\mathrm{III})}\right]^{+}$to $\mathrm{Cp}_{2}{ }^{*} \mathrm{Fe}^{(\mathrm{II})}$ in DCE during biphasic electrolysis. With $\mathrm{THxABF}_{4}$ as the supporting organic electrolyte, as no protons were pumped into the DCE phase, bulk electrolysis of $\left[\mathrm{Cp}_{2}{ }^{*} \mathrm{Fe}^{(\mathrm{III})}\right]^{+}$to $\mathrm{Cp}_{2}{ }^{*} \mathrm{Fe}^{(\mathrm{II})}$ took place, $\left[E_{\left[\mathrm{Cp}_{2}{ }^{*} \mathrm{Fe}^{(\mathrm{III})}\right]^{+} / \mathrm{Cp}_{2}{ }^{*} \mathrm{Fe}^{(\mathrm{II})}}\right]_{\mathrm{SHE}}^{\mathrm{DCE}}$ moved to more reducing (negative) values and the ratio of $\left[\mathrm{Cp}_{2}{ }^{*} \mathrm{Fe}^{(\mathrm{III})}\right]^{+}$to $\mathrm{Cp}_{2}{ }^{*} \mathrm{Fe}^{(\mathrm{II})}$ reached a steady-state with the electrode (the glassy carbon electrode was polarised versus a $\mathrm{Ag} / \mathrm{Ag}^{+}$ reference electrode in the organic phase, and thus $\Delta_{\mathrm{o}}^{\mathrm{w}} \phi$ did not influence the Nernst potential for cell 1).

With BATB as the supporting organic electrolyte, protons were pumped into the DCE phase (cell 2). Once more, the ratio

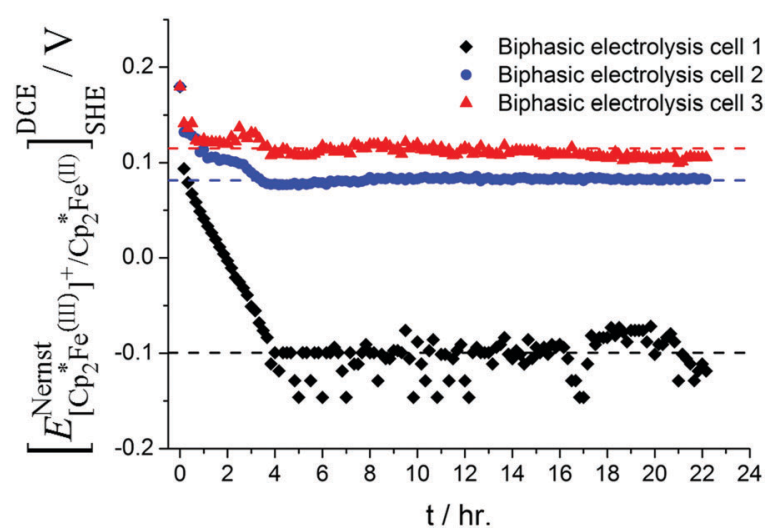

Fig. 5 Variation of the Nernst potential in the organic phase versus the standard hydrogen electrode (SHE), $\left.\left.\left[E_{\left[\mathrm{Cp}_{2}{ }^{*} \mathrm{Fe}(\mathrm{III})\right.}^{\mathrm{Nerns}}\right]^{+} / \mathrm{Cp}_{2}{ }^{*} \mathrm{Fe}^{(\mathrm{II})}\right]\right]_{\mathrm{SHE}}^{\mathrm{DCE}}$, during

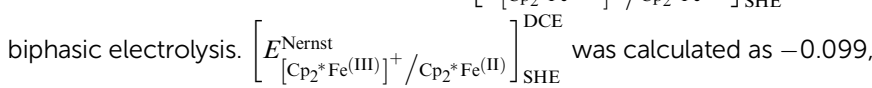

0.081 and $0.115 \mathrm{~V}$ for biphasic electrolysis cells 1,2 and 3 , respectively. of $\left[\mathrm{Cp}_{2}{ }^{*} \mathrm{Fe}^{(\mathrm{III})}\right]^{+}$to $\mathrm{Cp}_{2}{ }^{*} \mathrm{Fe}^{(\mathrm{II})}$ reached a steady-state. However, this was not a steady-state with the electrode. Instead, a substantial current flowed for the entire duration of electrolysis and $\left[E_{\left[\mathrm{Cp}_{2}{ }^{*} \mathrm{Fe}^{(\mathrm{III})}\right]^{+} / \mathrm{Cp}_{2}{ }^{*} \mathrm{Fe}^{(\mathrm{II})}}^{\mathrm{Nernst}}\right]_{\mathrm{SHE}}^{\mathrm{DCE}}$ was a measure of the driving force for the reaction at the electrode and the driving force for the homogenous $\mathrm{H}_{2}$ evolution reaction in DCE. A $35 \mathrm{mV}$ positive shift in $\left[E_{\left[\mathrm{Cp}_{2}{ }^{*} \mathrm{Fe}{ }^{(\mathrm{III})}\right]^{+} / \mathrm{Cp}_{2}{ }^{*} \mathrm{Fe}{ }^{(\mathrm{II})}}^{\mathrm{Nernst}}\right]_{\mathrm{SHE}}^{\mathrm{DCE}}$ to less reducing potentials was observed when $\mathrm{Mo}_{2} \mathrm{C}$ was present (cell 3) and this indicated that a process known as redox electrocatalysis takes place with $\mathrm{Mo}_{2} \mathrm{C} .{ }^{30,45-47}$ When more than one redox couple is present in DCE, as is the case for the $\left[\mathrm{Cp}_{2}{ }^{*} \mathrm{Fe}^{(\mathrm{III})}\right]^{+} / \mathrm{Cp}_{2}{ }^{*} \mathrm{Fe}^{(\mathrm{II})}$ and $\mathrm{H}^{+} / \frac{1}{2} \mathrm{H}_{2}$ redox couples herein, a thermodynamic equilibrium will be reached between both redox couples. However, due to kinetic limitations, the system may remain out of equilibrium. Thus, $\mathrm{Mo}_{2} \mathrm{C}$ can catalyse Fermi level equilibration between the two redox couples in solution. The net result is that higher current densities were obtained when $\mathrm{Mo}_{2} \mathrm{C}$ was present (see Fig. 3(A)), yet $30 \mathrm{mV}$ less polarization at the ITIES and $35 \mathrm{mV}$ smaller driving force for the hydrogen evolution (as calculated from the Nernst potential for the $\left[\mathrm{Cp}_{2}{ }^{*} \mathrm{Fe}^{(\mathrm{III})}\right]^{+} / \mathrm{Cp}_{2}{ }^{*} \mathrm{Fe}^{(\mathrm{II})}$ couple) was required to achieve this.

\section{Conclusions}

A completely new approach to electrolysis incorporating photoelectrochemical biphasic $\mathrm{H}_{2}$ evolution and water oxidation processes into the cathodic and anodic compartments of an H-cell, respectively, is introduced. Critically, both are achieved using reversible redox couples in the organic phases. The purpose of the polarised water-organic interface is multifold, ranging from acting as a proton pump to providing an ideal environment to facilitate photo-generated electron-hole separation. Using an $\mathrm{H}$-cell prototype capable of biphasic $\mathrm{H}_{2}$ evolution with a lipophilic, electrochemically reversible electron donor $\left(\mathrm{Cp}_{2}{ }^{*} \mathrm{Fe}^{(\mathrm{II})}\right)$, the vital necessity of super-hydrophobic organic electrolyte anions in the cathodic organic phase (to ensure proton transfer) was identified, as was the ability to enhance biphasic electrolysis efficiency by redox electrocatalysis using interfacial floating catalytic nanomaterials. Of course, the utilization of halogenated solvents on a large scale is very problematic from an environmental and health and safety point of view. However, for practical systems, toxic DCE could be replaced by less toxic trifluorotoluene, ${ }^{48}$ nitriles $^{9}$ or a series of recently proposed ketone $^{49,50}$ solvents suitable for electrochemistry at liquidliquid interfaces.

\section{Acknowledgements}

This publication has emanated from research by M. D. S. supported in part by a research grant from Science Foundation Ireland (SFI) under Grant Number 13/SIRG/2137. P. P. acknowledges the financial support from the Swiss National Science Foundation under Grant Ambizione Energy 160553. 


\section{Notes and references}

1 M. G. Walter, E. L. Warren, J. R. McKone, S. W. Boettcher, Q. Mi, E. A. Santori and N. S. Lewis, Chem. Rev., 2010, 110, 6446-6473.

2 L. G. Bloor, R. Solarska, K. Bienkowski, P. J. Kulesza, J. Augustynski, M. D. Symes and L. Cronin, J. Am. Chem. Soc., 2016, 138, 6707-6710.

3 M. P. Browne, H. Nolan, G. S. Duesberg, P. E. Colavita and M. E. G. Lyons, ACS Catal., 2016, 6, 2408-2415.

4 D. Schaming, I. Hatay, F. Cortez, A. Olaya, M. A. Méndez, P. Ge, H. Deng, P. Voyame, Z. Nazemi and H. Girault, Chimia, 2011, 65, 356-359.

5 N. Eugster, K. P. Sreenivasan, B. Su and H. H. Girault, Langmuir, 2006, 22, 1112-1120.

6 D. Plana, K. A. Bradley, D. Tiwari and D. J. Fermín, Phys. Chem. Chem. Phys., 2016, 18, 12428-12433.

7 R. Bourdon, P. Peljo, M. A. Méndez, A. J. Olaya, J. De JongheRisse, H. Vrubel and H. H. Girault, J. Phys. Chem. C, 2015, 119, 4728-4735.

8 Z. Samec, Pure Appl. Chem., 2004, 76, 2147-2180.

9 S. Rastgar, M. Pilarski and G. Wittstock, Chem. Commun., 2016, 52, 11382-11385.

10 I. Hatay, B. Su, F. Li, R. Partovi-Nia, H. Vrubel, X. Hu, M. Ersoz and H. H. Girault, Angew. Chem., Int. Ed., 2009, 48, 5139-5142.

11 P. Ge, T. K. Todorova, I. Hatay Patir, A. J. Olaya, H. Vrubel, M. A. Méndez, X. Hu, C. Corminboeuf and H. H. Girault, Proc. Natl. Acad. Sci. U. S. A., 2012, 109, 11558-11563.

12 P. Ge, A. J. Olaya, M. D. Scanlon, I. Hatay Patir, H. Vrubel and H. H. Girault, ChemPhysChem, 2013, 14, 2308-2316.

13 L. Rivier, T. J. Stockmann, M. A. Méndez, M. D. Scanlon, P. Peljo, M. Opallo and H. H. Girault, J. Phys. Chem. C, 2015, 119, 25761-25769.

14 M. A. Méndez, R. Partovi-Nia, I. Hatay, B. Su, P. Ge, A. Olaya, N. Younan, M. Hojeij and H. H. Girault, Phys. Chem. Chem. Phys., 2010, 12, 15163-15171.

15 J. J. Nieminen, I. Hatay, P. Ge, M. A. Méndez, L. Murtomäki and H. H. Girault, Chem. Commun., 2011, 47, 5548-5550.

16 N. Eugster, D. J. Fermín and H. H. Girault, J. Phys. Chem. B, 2002, 106, 3428-3433.

17 D. J. Fermin and R. Lahtinen, in Liquid Interfaces In Chemical, Biological And Pharmaceutical Applications, ed. A. G. Volkov, CRC Press, 2001, pp. 179-228.

18 L. Rivier, P. Peljo, L. A. C. Vannay, G. C. Gschwend, M. A. Méndez, C. Corminboeuf, M. D. Scanlon and H. H. Girault, Angew. Chem., Int. Ed., 2017, 56, 2324-2327.

19 H. Vrubel and X. Hu, ACS Catal., 2013, 3, 2002-2011.

20 I. Hatay, P. Ge, H. Vrubel, X. Hu and H. H. Girault, Energy Environ. Sci., 2011, 4, 4246.

21 T. Jane Stockmann, H. Deng, P. Peljo, K. Kontturi, M. Opallo and H. H. Girault, J. Electroanal. Chem., 2014, 729, 43-52.
22 J. Jedraszko, O. Krysiak, W. Adamiak, W. Nogala, H. H. Girault and M. Opallo, ChemElectroChem, 2016, 3, 1277.

23 W. Adamiak, J. Jedraszko, W. Nogala, M. JönssonNiedziolka, S. Dongmo, G. Wittstock, H. H. Girault and M. Opallo, J. Phys. Chem. C, 2015, 119, 20011-20015.

24 J. Jedraszko, W. Nogala, W. Adamiak, S. Dongmo, G. Wittstock, H. H. Girault and M. Opallo, Chem. Commun., 2015, 51, 6851-6853.

25 H. Deng, T. J. Stockmann, P. Peljo, M. Opallo and H. H. Girault, J. Electroanal. Chem., 2014, 731, 28-35.

26 A. J. Olaya, M. A. Méndez, F. Cortes-Salazar and H. H. Girault, J. Electroanal. Chem., 2010, 644, 60-66.

27 B. Hundhammer and T. Solomon, J. Electroanal. Chem., 1983, 157, 19-26.

28 B. Su, I. Hatay, F. Li, R. Partovi-Nia, M. A. Méndez, Z. Samec, M. Ersoz and H. H. Girault, J. Electroanal. Chem., 2010, 639, 102-108.

29 S.-Y. Chang, S. G. Booth, A. Uehara, J. F. W. Mosselmans, G. Cibin, V.-T. Pham, L. Nataf, R. A. W. Dryfe and S. L. M. Schroeder, J. Phys.: Conf. Ser., 2016, 712, 12058.

30 P. Peljo, M. D. Scanlon, A. J. Olaya, L. Rivier, E. Smirnov and H. H. Girault, J. Phys. Chem. Lett., 2017, 8, 3564-3575.

31 E. Aslan, I. Akin and I. Hatay Patir, ChemCatChem, 2016, 8, 719-723.

32 F. Ozel, E. Aslan, A. Sarilmaz and I. Hatay Patir, ACS Appl. Mater. Interfaces, 2016, 8, 25881-25887.

33 E. Aslan, I. Hatay Patir and M. Ersoz, Chem. - Eur. J., 2015, 21, 4585-4589.

34 F. Ozel, A. Yar, E. Aslan, E. Arkan, A. Aljabour, M. Can, I. Hatay Patir, M. Kus and M. Ersoz, ChemNanoMat, 2015, 1, 477-481.

35 S. G. Booth and R. A. W. Dryfe, J. Phys. Chem. C, 2015, 119, 23295-23309.

36 E. Aslan, I. Hatay Patir and M. Ersoz, ChemCatChem, 2014, 2832-2835.

37 A. N. J. Rodgers, S. G. Booth and R. A. W. Dryfe, Electrochem. Commun., 2014, 47, 17-20.

38 Y. Gründer, M. D. Fabian, S. G. Booth, D. Plana, D. J. Fermín, P. I. Hill and R. A. W. Dryfe, Electrochim. Acta, 2013, 110, 809-815.

39 M. D. Scanlon, X. Bian, H. Vrubel, V. Amstutz, K. Schenk, X. Hu, B. Liu and H. H. Girault, Phys. Chem. Chem. Phys., 2013, 15, 2847-2857.

40 E. Aslan, I. Akin and I. Hatay Patir, Chem. - Eur. J., 2016, 22, 5342-5349.

41 X. Bian, M. D. Scanlon, S. Wang, L. Liao, Y. Tang, B. Liu and H. H. Girault, Chem. Sci., 2013, 4, 3432-3441.

42 P. Ge, M. D. Scanlon, P. Peljo, X. Bian, H. Vubrel, A. O'Neill, J. N. Coleman, M. Cantoni, X. Hu, K. Kontturi, B. Liu and H. H. Girault, Chem. Commun., 2012, 48, 6484-6486.

43 L. Liao, X. Bian, J. Xiao, B. Liu, M. D. Scanlon and H. H. Girault, Phys. Chem. Chem. Phys., 2014, 16, 10088-10094.

44 L. Liao, S. Wang, J. Xiao, X. Bian, Y. Zhang, M. D. Scanlon, X. Hu, Y. Tang, B. Liu and H. H. Girault, Energy Environ. Sci., 2014, 7, 387-392. 
45 E. Smirnov, P. Peljo, M. D. Scanlon and H. H. H. Girault, Electrochim. Acta, 2016, 197, 362-373.

46 M. D. Scanlon, P. Peljo, M. A. Méndez, E. Smirnov and H. H. Girault, Chem. Sci., 2015, 6, 2705-2720.

47 E. Smirnov, P. Peljo, M. D. Scanlon and H. H. Girault, ACS Nano, 2015, 9, 6565-6575.
48 A. J. Olaya, P. Ge and H. H. Girault, Electrochem. Commun., 2012, 19, 101-104.

49 X. Zhang, S. Zhang, X. Zhang, M. Li, Y. Gu and Y. Shao, J. Electroanal. Chem., 2016, 781, 76-82.

50 P. S. Toth and R. A. W. Dryfe, Analyst, 2015, 140, 1947-1954. 